\title{
Beyond Massage Parlors: Exposing the Korean Commercial Sex Market in the United States
}

Youngbee Dale

Effective Communications Strategies, ybdale@gmail.com

Amy Levesque

University of Rhode Island, amy_levesque@my.uri.edu

Follow this and additional works at: https://digitalcommons.uri.edu/dignity

Part of the Community-Based Research Commons, Other Public Affairs, Public Policy and Public Administration Commons, Political Science Commons, Politics and Social Change Commons, Public Policy Commons, Social Policy Commons, Sociology of Culture Commons, and the Women's Studies Commons

\section{Recommended Citation}

Dale, Youngbee and Levesque, Amy (2017) "Beyond Massage Parlors: Exposing the Korean Commercial Sex Market in the United States," Dignity: A Journal of Analysis of Exploitation and Violence: Vol. 2: Iss. 4, Article 4. https://doi.org/10.23860/dignity.2017.02.04.04

This Research and Scholarly Article is brought to you for free and open access by DigitalCommons@URI. It has been accepted for inclusion in Dignity: A Journal of Analysis of Exploitation and Violence by an authorized editor of DigitalCommons@URI. For more information, please contact digitalcommons-group@uri.edu. 


\title{
Beyond Massage Parlors: Exposing the Korean Commercial Sex Market in the United States
}

\begin{abstract}
This paper describes the Korean commercial sex market in the U.S. beyond massage parlors. Prior to this study, the U.S. anti-trafficking efforts have heavily focused on combating massage parlors to fight prostitution and sex trafficking of Korean women in the U.S. This paper introduces the shift of trends taking place within the Korean sex market as a result of changing culture and policies. It then introduces various brothel models exploiting Korean women in the U.S. It also brings a more holistic view of the Korean sex market in the U.S. by relying on primary and secondary sources available in both Korean and English languages. The sources include interviews with law enforcement, Korean and American news articles, Korean non-governmental organization (NGO) reports that included interviews with victims, and the U.S. federal cases involving Korean prostitution and sex trafficking. Lastly, this paper examines the current challenges for the U.S. anti-trafficking efforts because of their insufficient understanding of the U.S. Korean sex market.
\end{abstract}

\section{Keywords}

Korean, United States, prostitution, sex trafficking, commercial sexual exploitation, massage parlors, norabang, doumi service, room salon, residential brothel, plastic surgery, law enforcement, massage parlor regulations, immigration policy, illicit market, economy, visa fraud

\section{Creative Commons License}

c) (i) $९$

This work is licensed under a Creative Commons Attribution-Noncommercial-No Derivative Works 4.0 License.

\section{Acknowledgements}

First and foremost, I, Youngbee Dale, am grateful to Lord Jesus for His favor and grace to finish this paper. Second, I want to thank my husband and best friend, Jonathan Dale, for his unwavering support and love. Third, I want to thank Melissa Farley and Laura Lederer for encouraging me to write this paper about Korean victims of prostitution. Lastly, but not the least, I want to thank the reviewers of this paper and editor Donna Hughes for their incredible patience, support, and belief in this paper. Dignity thanks the following reviewers of this article for their time and expertise: Jody Raphael, senior research fellow, DePaul University College of Law, USA, and Timothy Lim, professor of political science, California State University-Los Angeles, USA. 


\section{DIGNITY}

Volume 2, Issue 4, Article 4, 2017
A JOURNAL ON

SEXUAL EXPLOITATION

AND VIOLENCE

\title{
BEYOND MASSAGE PARLORS: EXPOSING THE KOREAN COMMERCIAL SEX MARKET IN THE UNITED STATES \\ Youngbee Dale \\ Anti-trafficking consultant, Effective Communications Strategies
}

Amy Levesque

University of Rhode Island

\begin{abstract}
This paper describes the Korean commercial sex market in the U.S. beyond massage parlors. Prior to this study, the U.S. anti-trafficking efforts have heavily focused on combating massage parlors to fight prostitution and sex trafficking of Korean women in the U.S. This paper introduces the shift of trends taking place within the Korean sex market as a result of changing culture and policies. It then introduces various brothel models exploiting Korean women in the U.S. It also brings a more holistic view of the Korean sex market in the U.S. by relying on primary and secondary sources available in both Korean and English languages. The sources include interviews with law enforcement, Korean and American news articles, Korean non-governmental organization (NGO) reports that included interviews with victims, and the U.S. federal cases involving Korean prostitution and sex trafficking. Lastly, this paper examines the current challenges for the U.S. anti-trafficking efforts because of their insufficient understanding of the U.S. Korean sex market.
\end{abstract}

\section{KEYWORDS}

Korean, United States, prostitution, sex trafficking, commercial sexual exploitation, massage parlor, norabang, doumi service, room salon, residential brothel, plastic surgery, law enforcement, massage parlor regulations, immigration policy, illicit market, economy, visa fraud

"[The doumi manager] told me that if I sell my body, he will pay off my debt sooner because I will get paid $\$ 500$ a night. I really don't want to prostitute... But, if I tell him no, he tells me to pay off my debt right away. I am not allowed to go anywhere. I am only allowed to go outside once a week with other doumi women" (The Reality of Prostitution, 2004).

\footnotetext{
$\mathrm{A}$ nti-trafficking organizations often describe Korean commercial sexual exploitation in the United States as primarily taking place in storefront brothels such as massage parlors. For instance, throughout the first decade of the $21^{\text {st }}$ century, many anti-trafficking advocates and law enforcement officials reported that Korean women were trafficked from South Korea to the U.S. to be exploited in massage parlors. However, massage parlors are only a segment of the commercial sex market exploiting Korean women in the U.S. Little is known about various brothels exploiting Korean women in the U.S. This limited understanding of the Korean commercial sex market and the operational tactics of perpetrators
} 
makes it difficult for law enforcement and non-governmental organizations (NGOs) to crack down on crime effectively.

This paper aims to provide a more comprehensive understanding of the Korean commercial sex market operating in the U.S. today. After reviewing earlier research focusing on storefront models such as massage parlors, this paper will provide information on other forms of exploitation, including room salons, doumi services, and residential brothels. It will also explore current trends taking place within the Korean sex market in the U.S. Lastly; this paper will discuss shortcomings that U.S. anti-trafficking organizations, advocates, and law enforcement face due to a limited understanding of the Korean commercial sex market operating in the U.S.

\section{Earlier Organization - Massage Parlors}

Scholars in the past investigated sex trafficking in massage parlors throughout the U.S. In 2008, Lim and Yoo shed light on 14 Korean women prostituted in massage parlors in the late 1990s and early 2000s. The study revealed that 60 percent of women were voluntarily smuggled into the U.S. (Lim \&Yoo, 2008, p. 24). One woman reported that she entered the U.S. on a student visa and another woman said that she entered the U.S. on a short-term tourist visa (Lim \& Yoo, 2008, p. 2124). Additionally, friends or acquaintances recruited 54 percent of the women to work in massage parlors, and 85.5 percent of the women admitted to staying in the U.S. illegally (Lim \& Yoo, 2008, p. 25). Fifty percent responded that they "had a job outside the sex or entertainment industry," and only one woman said that she worked as a prostitute in South Korea (Lim \&Yoo, 2008, p. 23). Sixty-four percent of the women alleged that they did not know they would engage in prostitution in the U.S. before leaving South Korea, and 54 percent reported that they were forced into prostitution after arriving the U.S. (Lim \& Yoo, 2008, p. 27).

The women said that they were subjected to coercion or force for the purpose of prostitution at some point (Lim \& Yoo, 2008, p. 35). Fifty-four percent stated that they were forced to engage in prostitution in the U.S. while others stated that they were coerced into sex related work in South Korea or Japan before entering the U.S. (Lim \& Yoo, 2008, p. 35). In sum, seventy-two percent of the women said that they were subject to force or coercion (Lim \& Yoo, 2008, p. 35).

The study shed light on cultural, political and socio-economic factors that pushed the women into prostitution in South Korea and the U.S. (Lim \& Yoo, 2008, p. 30). Women in South Korea face gender discrimination in the labor market and limited access to legitimate financial services (Lim \& Yoo, 2008, p. 35). The commercial sex market remains one of the few economically viable options for Korean women, as prostitution allows women to earn wages and pay off debts accrued with an exorbitant amount of interest (Lim \& Yoo, 2008, p. 35). In 1997, the International Monetary Fund (IMF) imposed neoliberal reforms to South Korea's financial market (Crotty \& Lee, 2006, p. 382). Consequently, the country adopted highinterest rates and a stringent fiscal policy leaving many Koreans with limited access to financial services (Crotty \& Lee, 2006, p 382). Individuals in need of loan services turned to the informal financial sector, which expanded from 3,000 companies in 1997 to 17,000 registered companies and 52,000 to 62,000 unregistered companies in 2007 (Lim \& Yoo, 2008, p. 34). The study revealed that private financing in South Korea reached \$175.5 million in outstanding loans in 2006 (Kim, 
2007). Private loan sharks imposed interest rates exceeding 200 percent per annum along with lending strategies to ensnare borrowers into a vicious cycle of debt (Kim, 2007). Nonetheless, the South Korean government provided no legal or institutional framework to protect borrowers against loan sharks. It also did not maintain a framework for personal bankruptcy for borrowers at the time of this research (Lim \& Yoo, 2008, p. 34). Therefore, private loan sharks used debt as a way to entice women into entering the commercial sex market domestically and internationally (Lim, 2008, p. 34).

In 2009, a survey of massage parlor managers, sex trafficking victims, and prostituting women shed light on women's demographics, religious backgrounds, marital statuses and employment histories prior to entering the U.S. It also analyzed criminal network models and illegal activities that occurred in massage parlor networks throughout the U.S., including money laundering, smuggling, and bribery. The study estimated the size of the Korean massage parlor economy in the U.S. and calculated the yearly earnings of massage parlor managers and prostituted women. For instance, massage parlor managers earned between $\$ 500,000$ and \$1,000,000 each year (Jang, Choo, \& Choi, 2009, p. 82). At the time of the study, all of the sex trafficking victims and prostituting women were staying in the U.S. illegally. Korean women entered the U.S. from South Korea with legal visas to engage in prostitution and stayed in the U.S. after their visas expired (Jang et al., 2009 , p. 78). Sixty-seven percent of women said that they entered the U.S. to pay off debts accrued in South Korea (Jang et al., 2009, p. 82), and many of the women stated that they would like to own and operate their own massage parlors in the U.S. (Jang et al., 2009, p. 87).

The study also analyzed the 2006 Federal case, Operation Cold Comfort, which provides information on the multi-layer criminal business model of the Korean massage parlor network in the U.S. The case included the arrests of 30 parlor owners, two managers, five delivery brokers, and two financial agents. In this case, massage parlors were located in multiple states, including New York, Maryland, Washington D.C. and Pennsylvania (Jang et al., 2009, p. 84), and the criminal network involved upheld relational ties, such as family and neighborhood connections. One individual owned nine massage parlors; however, he rarely visited each establishment. Each massage parlor had a different owner on paper (Jang et al., 2009, p. 86). A financial broker laundered money by using his wife as a middleman to transfer funds through the Hawala system, an ancient Muslim remittance system in which a person instructs another person in a remote area to pay a final recipient (Jost \& Sandhu, n.d.). According to Jang et al., Hawala is also a method used for financing terrorism (Jang et al., 2009, p. 87).

Jang et al. examined massage parlor owners' operational methods. For instance, massage parlor owners throughout the U.S. bribed law enforcement, collected information on law enforcement tactics, closed old and opened new massage parlors, instructed taxi drivers and agents to transport women to and from massage parlors, and provided condoms and other necessities for sexual services. Owners drafted false legal documents to recruit women from brokers and rotated women every three to four weeks to keep faces fresh in brothels. Moreover, two women reported that they received breast augmentations by way of plastic surgery upon the request of owners and buyers (Jang et al., 2009, p. 86).

Analysis of American news articles on Korean prostitution suggests that media may be painting a slanted picture of the U.S. sex market exploiting Korean women. 
Although Korean media reports on various brothels exploiting young Korean women in their 20s, many American news articles do not reflect the same phenomenon (Prostitution widespread among Norabang, 2009; Bue, 2014; Bue, 2016; Lee, 2014). Instead, American news articles on Korean prostitution suggest that the age of Korean victims in parlors is much older. For instance, in this study, 34 online articles reported between 2006 and 2016 were collected on Korean prostitution, and 75 percent of them reported the arrests of women in their 40s. Thirty-seven percent of women arrested in massage parlors between the ages of fifty and sixty, and only 25 percent of the women arrested who were prostituting in massage parlors were between in the ages of 30 and 40 . However, only three articles advertised women in their twenties, and these arrests were made at residential brothels or doumi services, rather than in massage parlors or other storefront brothels (Jackman, 2011; Fisher et al., 2012; Green, 2016). This collection of news articles suggests a shift in the age demographics among women prostituted in Korean massage parlors in the U.S. Although mainstream U.S. media, like San Francisco Chronicles, report stories of sex trafficking victim in early 20s in 2006, this collection of new articles shows no arrests of women in their twenties for prostitution at massage parlors or storefront brothels (May, 2006; Kelsi, 2014).

The studies and news media analysis above provide insight on the sexual exploitation of Korean women in the U.S. in massage parlors. However, it is important to illuminate additional aspects of the Korean commercial sex market in the U.S. to fully understand and combat ongoing sexual exploitation and criminal activities.

\section{New Trafficking Techniques}

Unlike massage parlors, scholars have not investigated other venues for Korean commercial sex in the U.S. prior to this study. Therefore, this study relies on newspaper reports and internet website content advertising Korean commercial sexual services in the U.S. This study also relies on both Korean and English sources to provide a more comprehensive understanding of the Korean commercial sex market in the U.S. This study relies on Korean NGO reports quoting interviews with Korean victims exploited through commercial sex. It analyzes Korean media reports on interviews with Korean women, taxi drivers, a patron, and other individuals involved in the Korean commercial sex market in the U.S. For instance, an interview with Bue Sohyun, a Korean journalist, suggests that prostitution in the Korean American community is a widely known phenomenon. Bue, a general manager of a major Korean media, JTBC Los Angeles Office, who resided in a Korean community also interviewed Korean women in prostitution in the U.S. (Bue, 2016; Bue, 2014). Bue stated that prostitution in Korean American communities has always been a problem and she reported on newly emerging trends in the Korean commercial market in the U.S. (personal communication, June 1, 2017).

\section{Visa and Identity Fraud}

Perpetrators who exploit Korean women often rely on fraudulent visas to commit illegal activities. In U.S. $v$. Won in 2011, Taesan Won arrived in the U.S. with a tourist visa. A few months later, he applied for a student visa to extend his stay in the U.S. Even though Won's student visa prohibited him from working in the U.S., he operated a doumi business that employed Korean women (U.S. v. Won, 2011). Won's visa fraud is not an isolated incident. In 2012, Miyoung Roberts was sentenced two years in prison for committing immigration fraud (ICE, 2013). Roberts 
arranged for more than a dozen women to enter the U.S. illegally to engage in commercial sex. She also recruited a man to act as her co-conspirator who obtained citizenship through a sham marriage. When the women arrived in the U.S. from South Korea, Roberts arranged for their employment in room salons in Texas, New York, Colorado, and New Jersey (ICE, 2013). During the same year in another state, English language school officials and a Korean publisher were indicted for issuing fraudulent student visas to bring women into the U.S. to work at local bars and room salons (English Language School Officials, 2013). School officials included the owner of the Korea Times Atlanta (Georgia Asia Times, 2013) and other networks of individuals. Another defendant provided false passports, I-94 forms, bank account statements and additional documents to obtain F-1 student visas to bring women to the U.S. to work in room salons in California (English Language School Officials, 2013). In Hawaii in 2012, a broker was arrested possessing multiple passports and identity cards. After entering the U.S. with a tourist visa in 1998, Young Mo Sung obtained several Korean passports and Korean American identity cards to launder more than $\$ 5$ million from Los Angeles to Hawaii for women prostituted in massage parlors and hostess bars (Dooley, 2012). On one occasion, Sung obtained a false passport and visa from another broker to travel to Chicago with a group of people to take a driver's license exam (Dooley, 2012). This evidence shows that brokers performing adjacent criminal activities are vital to the operation of the Korean commercial sex industry in the U.S.

\section{Korea's Labor Industry Impact}

Korean newspapers reveal that Korea's domestic labor market encourages young people to study abroad, causing Korean youth to become vulnerable to commercial sexual exploitation. According to the Korean media, South Korea's employment industry encourages young Koreans to study in the U.S. and in other countries to acquire better job opportunities (Noh, 2016; Yoon, 2011). In this study, the researcher found that advertisements are selling Korean women in their early 20s for commercial sex in the U.S. on Backpage.com (Backpage.com, 2016). Additionally, a college student posted a message on a commercial sex industry forum in Korea looking for women to accompany her to enter the U.S. to engage in prostitution in December 2016 (Anonymous, 2016). The student said that she wanted to partake in commercial sex in the U.S. to pay off her college tuition during winter break (Anonymous, 2016). Some brokers also use F-1 student visas as a way to traffic women into the U.S (Eun, 2009). Other victims enter the U.S. with F-1 student visas and become doumi or room salon hostesses to fund the cost of study abroad programs (Report on Korean Prostitution, 2012).

\section{Plastic Surgery}

A recent increase in the popularity of plastic surgery in South Korea has led to an increase in plastic surgery in the Korean commercial sex market in the U.S. In Korean culture, people believe that physical attractiveness leads to better employment opportunities and happier lives (McMar, 2015; Baer, 2015; Makeup grows in popularity among, 2012). According to Dr. Choi Hang-Seok, a Korean plastic surgeon treating 10,000 patients every year, Koreans believe that better-looking people have more employment opportunities as employers require all potential employees to include photos in their resumes (Baer, 2015). Such a phenomenon also influences the Korean commercial sex market (A Man sold Korean women, 2006; Yoo et al., 2016). Some women in prostitution endure plastic surgery voluntarily, while others receive plastic surgery at the request of johns or pimps (Jang et 
al., 2009; Moon, 2015). In other cases, perpetrators use plastic surgery as a mechanism to recruit young women into the commercial sex market or to drive victims already being sexually exploited into deeper debt (Yoo et al., 2016; Lee, 2016). Korean media reports also reveal that Korean women in prostitution in the U.S. often endure plastic surgery (Yoo et al., 2016; Jang et al., 2009; L.A. Korean prostitution, 2013). A 2006 report stated that brothel owners forced women into debt by pressuring them into having plastic surgery (A Man Sold Korean Women, 2006). Additionally, in 2013, police arrested a network of brothel owners who forced women into prostitution in Los Angeles, New York, and Hong Kong. One manager in Los Angeles coerced women into enduring plastic surgery, advertised women online for sex and arranged commercial sex transactions with Johns at hotels (L.A. Korean Prostitution, 2013). Furthermore, in the Jang et al. study, two women reported that they received breast augmentations at Johns' and managers' requests (Jang et al., 2009, p 86). However, the study did not indicate whether the women received plastic surgery in South Korea or the U.S.

Websites that recruit women into the Korean commercial sex industry also advertise financial services that offer to help finance plastic surgery and the cost of living during recovery periods (Yoo et al., 2016; Badalba.com, 2017). Advertisements target young women who want to have plastic surgery but cannot afford procedures. Loan sharks provide funding with high-interest rates to cover the cost of procedures, so women end up in debt, which they are forced to pay off through prostitution. Additionally, online advertisements often publicize women's breast sizes as C or D. However, a study in 2013 revealed that the average breast size of Korean women was 87.04 centimeters, a size equivalent to the U.S. bra size A cup (Cho \& Kim, 2012).

Reports by Korean nonprofits also provide a greater understanding of how traffickers use plastic surgery as a mechanism to lure young women into debt bondage or drive sex trafficking victims into deeper debt for the purpose of prostitution. Although reports are based on interviews with Korean women in prostitution in the U.S., they reveal that business trends in Korean communities in the U.S. often mirror those that take place in South Korea (Ofek et al., 2015; Ramirez, 2017). For instance, in 2016, the director of Korea Women's Home, a shelter providing services to victims of sexual exploitation in South Korea, identified plastic surgery as one of the three main mechanisms used for sexual exploitation under debt bondage, along with drugs and alcohol (Lee, 2016). Lee shared stories about clients who amassed large debts after being pressured by madams into receiving plastic surgery

(Woman \#9): Botox injection(s) (facial), breast augmentation(s), nose lift(s), and eyelid lift(s) are normally expected. The surgery cost(s) range between $\$ 10,000$ and $\$ 30,000$, and you generally have to prostitute to pay off that debt. But you can never say no to your madam. If you do, she'll never let you see the Johns, then you'll never pay off your debts, period. Even if you don't see Johns one day, it gets you in trouble (because of compound interest rates) (Lee, 2016, p. 69)

(Woman \#10): I thought I almost paid off my debt (in) less than three years, (but) my madam asked me to get surgery for (a) breast augmentation. I had to borrow $\$ 20,000$ from a loan shark, and I found out that the surgery only cost $\$ 10,000$. I think that the rest of $\$ 10,000$ was for the madam for brokerage fees. That's how madams make money when girls 
receive plastic surgery. But, you can't say no to your madam. If you say no, she'll never let you have a table or a room to see the Johns. Then, your interest rates and debt amount (increases) every day, and you'll never get out of the debt (Lee, 2016, p. 69).

(Woman \#11): "The most expensive surgery is called "dental lamination." - It's a dental plastic surgery that is supposed to make your teeth look like those of celebrities or TV personalities. The cost of the surgery ranges between $\$ 10,000$ and $\$ 20,000$. And, you can't really work for a month during the recovery, so the cost of living expenses for that recovery month is added to your debt. But you really can't say no when your madam asks you (Lee, 2016, p. 69).

In 2016, E-loom, a nonprofit that assists women in the commercial sex industry in South Korea, reported that loan sharks used plastic surgery to recruit women for prostitution (Yoo, Chong, Won, \& Kim, 2016). Loan sharks and pimps lured and trapped women in prostitution by way of deceptive offers, such as plastic surgery (Yoo et al., 2016, p. 6). According to one report, one of E-loom's clients was recruited through an online advertisement, which offered to finance the cost of plastic surgery for women. At that time, the client was looking for a way to pay for plastic surgery, as she wanted to pursue a career in the television industry. During an initial meeting, the loan shark told the woman that she could pay off the plastic surgery loan if she maintained a high paying part-time job for two months after receiving the surgery. He introduced her to a plastic surgeon that recommended cheekbone reduction, a breast augmentation, eyelid surgery, a nose lift, and a chin reduction (Yoo et al., 2016, p. 6). The surgery cost $\$ 22,000$, and she financed $\$ 12,000$ with the help of the loan shark, and she paid the remaining balance through daily installments (Yoo et al., 2016, p. 6). She later discovered that the loan shark worked as a broker for plastic surgeons, and the plastic surgeon paid the loan shark 30 percent of the profits he made (Yoo et al., 2016, p. 7). The loan shark brought the woman to a room salon to pay off her debt, where she was told that she had to pour drinks for the customers. However, she was forced to engage in prostitution against her will to pay off her loan. The woman's loan, along with highinterest rates, increased from $\$ 22,000$ to $\$ 70,000$, which required her to file for bankruptcy (Yoo et al., 2016, p. 8).

\section{Immigration Policy Impact}

Korean news reports, a legal case, and additional studies reflect the impact of changing U.S. immigration policies on Korean prostitution in the U.S. (Jang et al., 2009; United States v. Kim et al., 2016, p. 10; Kang, 2013; Choi, 2015; Lee, 2016; Park, 2013; Moon, 2014; Bue, 2016). For instance, before 2008, traffickers worked with smugglers to traffic women into the U.S. through Canada and Mexico (Han, 2012). However, in 2008, the U.S. government implemented the visa waiver program, allowing South Korean nationals to travel to the U.S. for up to three months without a visa (Yu, 2008). As a result, more traffickers sent Korean women to the U.S. using the visa waiver program to engage in prostitution (Kim, 2011). Some women overstayed their visas and disappeared into Korean communities in the major cities across the U.S. (Bue, 2016). Women trafficked in South Korea or Japan are also re-trafficked in the U.S. by way of the visa waiver program (Hwang, 2016). In one case, traffickers disguised sex trafficking victims as tourists by instructing them to speak and act in certain ways to avoid being detected by immigration law 
officers at airports. The women were given cameras and tourist brochures to appear as though they were entering the U.S. willingly (Women Prostituted Abroad, 2016).

\section{New Prostitution Models}

Korean perpetrators prostitute Korean women in the U.S. in various brothel models, such as hostess bars (room salons), doumi services, high-class escort service (GFE brothels), and residential brothels. They often replicate successful business models operating in South Korea in the U.S. (Ofek, Kim \& Norris, 2015). Thus, the following section analyzes business models and tactics used by Korean traffickers to exploit women in the U.S.

\section{Hostess Bars (Room Salons)}

Hostess bars or room salons are one of the oldest and most well-known business models in the Korean commercial sex industry (Choi, 2006, p. 105; Hong, 2005). Women working in hostess bars are forced into debt bondage for the purpose of prostitution. Brokers impose loans upon women trafficked from South Korea into the U.S. to cover the cost of their travel expenses. Women are told that they will work for madams in hostess bars and that they have to serve expensive appetizers and drinks to customers who spend between $\$ 1,000$ and $\$ 2,000$ a night on food and beverages. Initially, they are often told that they do not have to prostitute themselves to pay off their debt. However, many women discover that without engaging in prostitution, it is impossible to pay off their debt due to the added cost of compound interest rates (Huh, 2012; Moon, 2015; Lee, 2016, p. 69; Choi, 2006, p. 105; Hong, 2005; Shin, 2016). Many women are trapped in debt bondage in hostess bars in South Korea as well. The executive director of a women's shelter aiding sexually exploited victims in South Korea reported that women are prostituted through debt bondage in four out of ten room salons (Shin, 2016).

It is unknown how many women are trafficked into hostess bars in the U.S. However, an increase in the Korean population in parts of the U.S. has resulted in an increase in the number of hostess bars in operation (Chris, 2015; 3-6-9, 2014; Ramirez, 2017; Choi, 2012; Shin, 2016; L.A.BamSarang.com; n.d. ; L.A. Bam Alba, n.d.; Huh, 2012). Also, hostess bars have a longer history of operating in the U.S. than other brothel models (Hong, 2005; Special Report Team, 2012; Chang, 2015).

Legal cases also demonstrate that hostess bars in the U.S. have been used as an avenue for sex trafficking. In 2003, a Korean couple in Queens, New York, owned a hostess bar known as Renaissance and recruited women from South Korea to work at their business (Yushuvayev v. United States, 2008). Court documents reveal that the male trafficker hit or slapped the women and locked them in his residence. On one occasion, he locked a woman in the basement of his house for two days and told her that he wanted to kill and sell her. The woman was released after she apologized to him. On another occasion, the trafficker left a threatening voicemail on a victim's cell phone after discovering that she and another victim left his house without his permission. When the victims returned they were forced to kneel before their trafficker as he "screamed obscenities" and kicked one woman in the head until she lost consciousness. One victim also told police that her trafficker tried to force her into prostitution by raping her, and another woman reported that she overheard her manager negotiating the price of her body while on the phone with a Chinese brothel owner (Yushuvayev v. United States, 2008). In 
2015, one woman described her experience working at room salon in Los Angeles. While in prostitution in Japan, a broker convinced her that she would earn a higher income as a prostitute if she traveled to the U.S. (Moon, 2015). Upon arriving in the U.S. her income increased; however, she was forced to spend the majority of her money paying off the debt that she owed to brokers and her room salon madam. She was also forced to engage in sexual activities with johns against her will (Moon, 2015).

Additionally, online advertisements and news articles demonstrate that a number of hostess bars successfully operate throughout the U.S. (L.A. Bam Alba, 2015; Citivue, 2017). For instance, in 2013 a Korean hostess bar madam was sentenced to two years in prison for recruiting and harboring women to work in hostess bars in Colorado, Texas, New Jersey and New York (Chong, 2013). In August 2016, the Korean Times reported that federal agents shut down two hostess bars and arrested fourteen people in Duluth, Georgia (Park, 2016). Furthermore, Korean hostess bars recruit women for prostitution through online advertisements. Websites such as Bamalbaworld.com and LAbamalba.com list hostess bars offering women high paying jobs. The website New York Bam Alba also lists at least 30 room salons operating in New York (NY Bam Alba, n.d.). Another website, Citivue, features patrons' reviews of women at hostess bars in New York (Cityvue, 2017). An online yellow page ad showing the addresses of Korean American businesses lists eighteen room salons operating in Hawaii (Korea Daily Address Book, n.d.). The majority of the hostess bars on Korea Daily Address Book are located in Honolulu; however, some of the hostess bars are situated in Wailuku and Waipahu (Korea Daily Address Book, n.d.). Websites shed light on the widespread existence of Korean hostess bars in the U.S.

\section{Doumi Service}

While hostess bars function as brothels wherein women are prostituted and brokers and madams profit from their earnings, doumi services in the U.S. operate as escort services where women act as call girls for sex buyers who hire them for entertainment and to perform sex acts at private parties, hotels, or at norabangs, which are Korean karaoke bars (L.A. Bamsarang, n.d.; Prostitution Widespread Among Norabang, 2009; the Reality of Prostitution in L.A., 2004). Unlike hostess bars, doumi services deliver women to various locations upon patrons' requests. A room salon manager in Los Angeles stated that doumi services operate as call girl services, and prostitution is more common among doumi women than women in room salons in L.A. (Prostitution Widespread Among Norabang, 2009). Depending on the doumi service agency, women are forced to perform sexual services that range from unwanted touching at norabangs to prostitution at residential brothels (Cho \& Kim, 2016; Norabang doumi lured with, 2014). No scholars to date have conducted studies investigating doumi services in the U.S.; however, KoreanAmerican news articles report on interviews with law enforcement, brothel managers, taxi drivers, and customers in the Korean language.

A legal case in 2011 reveals how doumi services operate in the U.S. A man by the name of Taesan Won, living in Fairfax, Virginia, recruited women from South Korea to enter the U.S. illegally to work as escorts for his doumi service Honey (United States $v$. Won, 2011). His partner Kim operated a doumi service known as A Plus. Won advertised his doumi service in Korean magazines and transported women to local norabangs and other locations after receiving customers' calls requesting escorts. Won charged customers $\$ 70$ an hour to sing, dance and converse 
with the women. On average, the women received $\$ 50$ and the remaining $\$ 20$ went toward Won's business. However, each woman paid Won an additional $\$ 100$ each week for room and board. Won claimed that his business made $\$ 30,000$ to $\$ 40,000$ each month, amounting to half a million dollars each year.

In 2016, the L.A. Korea Daily reported on interviews with doumi service managers and norabang owners (Prostitution Penetrates Korean Town, 2016). In a 2014 report, a norabang manager said that for every $\$ 120$ doumi women earned for singing and dancing with patrons, they paid doumi service managers $\$ 40$ (Bue, 2014). In addition, doumi women are often Korean college students in the U.S. hoping to earn enough money to pay their college tuitions and living expenses (Prostitution Penetrates Korean Town, 2016; Lee, 2014). One patron reported that he was stunned to meet a doumi woman enrolled in a prestigious university in the Los Angeles area who told him that doumi services were popular part-time jobs for Korean and Korean American students (Lee, 2014). Many Korean Americans in their 20s and 30s, often from states in the Midwest, work as doumi women (Prostitution Penetrates Korean Town, 2016), and doumi women travel from South Korea to the U.S. illegally to engage in prostitution in the U.S. (Chang, 2015; Lee, 2015). Doumi service employers harbor women in apartments and charge them for room and board expenses (Lee, 2014; United States $v$. Won, 2011). Additionally, doumi services are often highly profitable, as owners conduct cash transactions with customers, profiting from tax evasion (Prostitution Penetrates Korean Town, 2016).

In many cases, Korean doumi women are forced into prostitution through debt bondage (The Reality of Prostitution in L.A., 2004). During an interview with a news reporter, one victim stated that her debt increased from $\$ 9000$ to $\$ 36,000$ after traveling from South Korea to L.A. to work as a doumi. Her doumi manager charged her monthly fees for her cell phone, housing and brokerage for her I.D. (The Reality of Prostitution, 2004) Another doumi woman stated that her manager coerced her into engaging in prostitution to pay off her debt (The Reality of Prostitution, 2004).

[The doumi manager] told me that if I sell my body, he will pay off my debt sooner because I will get paid $\$ 500$ a night. I really don't want to prostitute... But, if I tell him no, he tells me to pay off my debt right away. I am not allowed to go anywhere. I am only allowed to go outside once a week with other doumi women (The Reality of Prostitution, 2004).

In 2015, some women were deceived into coming to the U.S. under the pretense that they would receive Hollywood entertainment jobs. However, they were coerced into becoming doumi women for prostitution after arriving in the U.S. (Oh, 2015). Police in Los Angeles arrested brokers who trafficked Korean college students to the U.S. for doumi prostitution (Oh, 2015). The women entered the U.S. by way of a visa waiver program, which allowed them to travel to the U.S. for up to three months. The brokers provided them with a luxurious lifestyle until their visa waiver period expired. However, the women were trapped in debt bondage and were told that they had to pay off the expense of their luxurious lifestyle, including the cost of housing, transportation and food that was offered to them for three months. Consequently, the women were forced to become doumi and were pressured into prostitution to pay off their debt (Oh, 2015). Brokers threatened the 
women that they would tell their families and friends in South Korea about their prostitution in the U.S. if they attempted to escape (Oh, 2015).

Therefore, while doumi services are not widely known to many anti-trafficking organizations and law enforcement in the U.S., evidence, as discussed below, reveals that doumi services exploit Korean women in the U.S.

\section{High-Class Online Escort Services (GFE)}

During the past few years, the U.S. commercial sex market for Korean women has become more hidden and lucrative. Traffickers have not only continued to prostitute women in storefront brothels, such as massage parlors, but have also been advertising prostitution online and in indoor brothels to stay under law enforcement's radar. In 2016, U.S. v. Kim et al. provides an example of a new method of sexual exploitation called "the girlfriend experience" (GFE). GFE is a sex act that includes kissing and not using a condom during sexual intercourse. Although not all women in brothels are involved in GFE, in U.S. v. Kim et al., a federal agent stated that every brothel retained at least one woman sold for GFE sex acts. Online advertisements indicated which women performed GFE activities by placing the acronym GFE next to their photographs. Women were shown dressed in lingerie with phrases such as "First time in the USA" or "New" next to their images (United States v. Kim et al., 2016).

News articles and online advertisements demonstrate that GFE brothels, such as those described in U.S. v. Kim et al. are in operation in other locations throughout the U.S. In 2012, police in New York arrested a trafficker for prostituting a Korean woman and other victims (Dooley, 2012). The brothel was situated in a commercial building and the trafficker lured in johns through online advertisements on the website "E4A Korea," which offered GFE services (Fisher, Cunningham, \& Hutchinson, 2012). Furthermore, online advertisements reveal where GFE brothels are located, and GFE brothels charge double the rate that most massage parlors charge for commercial sex throughout the U.S.

\section{Residential Brothels}

Moreover, previous studies offer a limited amount of insight into the operational methods of residential brothels (Lim \& Yoo, 2008, p 52; Jang et al., 2009, p 28; May, 2007). However, Korean newspapers report on an increasing number of incidents in residential brothels through interviews with insiders of the Korean commercial sex market. The Korean-American media serves as the main source of information on residential brothels because of its ability to access information within Korean-American communities, and due to the hidden nature of, and limited information available on, residential brothels (Bue, 2016; Oh, 2014; Huh, 2012). For instance, in 2016, a Korean journalist reported on an interview with an insider of Korean prostitution in San Francisco. The insider said that residential brothels maintain regular customer lists and advertise prostitution on their websites, and brothel owners close and launch website every three months to avoid detection by law enforcement. Residential brothel owners also contact Johns personally to avoid encountering undercover agents (Kim, 2016; United States $v$. Kim et al., 2016). What is more, a news article in 2009 revealed that residential brothel owners advertise prostitution on websites such as Craigslist (Kwak, 2009). Evidence also shows that residential brothel owners use a popular smartphone application called Kakao Talk to advertise commercial sexual services of Korean women to buyers (United States v. Kim et al., 2016; Park, 2013). 


\section{THE CURRENT PROBLEM}

Korean traffickers use various brothel models to exploit Korean women in the U.S. However, evidence reveals that U.S. anti-trafficking efforts may have shortcomings due to a limited understanding of the Korean sex market in the U.S. This section provides information on the shortcomings in legislation, law enforcement investigations, and media reporting on the Korean commercial sex market in the U.S.

\section{Legislative Changes}

Legislative changes in the U.S. have caused a shift to occur in the Korean commercial sex market. During the past few years, some state and local authorities began regulating massage parlors and licensure for masseuse practitioners to combat sex trafficking. In 2009, Texas adopted legislation prohibiting sexually oriented businesses, such as massage parlors, from obtaining licenses (Texas Administrative Code, 2009). Additionally, in 2010, Georgia legislators passed a bill to strengthen state regulations on massage parlors and masseuse practitioners. The bill made it a misdemeanor offense for parlors to offer sexual services, and to advertise dating, escort, or adult entertainment services along with massage. It also made it unlawful for practitioners to offer massage therapy without licenses and for massage parlor owners to employ unlicensed massage therapists. The bill gave the state Board of Massage Therapy the power to issue, reprimand and deny message therapy licenses to licensees. Crimes became punishable by imprisonment for a term lasting between one to five years, or a fine of up to $\$ 25,000$, or both. Board of Massage Therapy also gained the power to impose fines up to $\$ 500$ every time licensees were charged with being in violation of their license (SB 364, 2009).

Since 2007, 38 states have passed legislation regulating massage therapy (Proffitt, 2007). For instance, California passed laws to combat sex trafficking of Asian women in massage parlors. In 2014, a law was passed which listed reasons for denying massage therapists' certificates (Gold, 2014). The list comprised of "engaging in sexual suggestive advertisements, engaging in any form of sexual activity on the parlor premises, practicing massage therapy with a suspended certificate, and attempting to procure a certificate by fraud, misrepresentation or mistake" (AB1147, 2013). The legislation also listed reasons for disciplining massage certificate holders and included phrases including "engaging in unprofessional conduct" (AB1147, 2013). In 2014, an amendment to the state provision granted more power to local governments to enforce ordinances against massage parlors and massage license holders in their own jurisdictions (Feather, 2014). The new law mandates that certification applications of registered sex offenders are denied and their current certifications are revoked (AB 2194, 2014). These laws allow local officials from the City Department of Health to inspect massage parlors. Inspections are unannounced and cities have the ability to distinguish between legitimate and illegitimate parlors that are operating as brothels.

\section{Shortcomings of Massage Parlor Legislation}

Online prostitution advertisements and Korean news reports reveal that legislative changes impacting massage parlors might be causing Korean brothels to hide their operations. Korean news articles report an increasing number of brothels operating in hidden locations as a result of strict parlor regulations enforced by local law enforcement (Chang, 2015; Lee, 2011). Many parlors also continue to advertise 
prostitution online through individual websites, even though local jurisdiction criminalizes their behavior (Chang, 2015). Therefore, law enforcement needs to come up with newer ways of regulating massage parlors to combat the problem.

\section{Law Enforcement}

Evidence also demonstrates that some federal and local law enforcement officers may be operating on limited information while combating Korean sex trafficking or prostitution in the U.S. Interviews with law enforcement have offered some valuable insight into Korean massage parlor operation; however, many law enforcement officials are not aware of other brothel models exploiting Korean women.

During a 2016 interview a law enforcement officer in Virginia revealed that he dealt with prostitution and trafficking in massage parlors for more than ten years; however, at the time of the interview, he no longer considered Korean massage parlors to be a problem:

We do not see any young Korean women prostituted in massage parlors anymore. It was ten years ago. We got rid of them. We only see Chinese women prostituted around this area (Anonymous, Personal Interview, April 19, 2016).

The official said that his state did not require law enforcement to complete antihuman trafficking training. However, he trains law enforcement in other jurisdictions based on knowledge gained in massage parlor investigations. Yet, he only offers training to those interested in receiving it. Nonetheless, as previously stated, the official was not aware that Korean women were prostituted online and in residential brothels in his district (Anonymous, Personal Interview, April 19, 2016). Ironically, his state is listed as a state that mandates or encourages anti-human trafficking training for law enforcement (Polaris Project, 2014). This discrepancy suggests that states encouraging law enforcement officials to receive training on human trafficking may not be doing so effectively.

During another interview, a retired FBI agent and law enforcement trainer who provided anti-trafficking training to law enforcement around the U.S. stated that law enforcement often hesitates to invest in anti-trafficking training, especially if their state does not mandate it. In states where training is encouraged, the state might create an online training module with information on human trafficking; however, this does not guarantee that law enforcement will be trained to combat traffickers efficiently. He also stated that as a federal agent, he observed that investigations of trafficking were often dependent upon whether supervisors made trafficking a priority amongst other criminal cases. He also alleged that it often makes a difference if ten investigators, rather than one in each unit, are designated to investigate human trafficking cases. Lastly, he stressed the importance of community and nonprofit efforts in urging law enforcement to make human trafficking a primary concern (Anonymous, Personal Interview, November 4, 2016).

Another law enforcement official made a similar observation. In his case, he was assigned to work in a records department, while another official was put in charge of human trafficking. Human trafficking training was not mandated in his jurisdiction so it was not considered a priority within his police department. However, when local nonprofits voiced their concerns, his superior assigned a second 
officer to investigate human trafficking, regardless of his lack of experience (Anonymous, Personal Interview, September 17, 2014).

As mentioned above, these officers provided some valuable insight regarding sex trafficking in Korean massage parlors. However, they have demonstrated that they have little to no knowledge about other Korean brothel models operating in the U.S.

\section{The "Push Down and Pop Up" Effect}

An interview with law enforcement in another jurisdiction further reveals the need for a better understanding of the Korean commercial sex market in the U.S. among law enforcement. During the interview, one law enforcement official stated that even when his team shut down one massage parlor suspected of prostitution and human trafficking, another massage parlor with a different name would open in the same location the next day. He said that this phenomenon has made it almost impossible to combat the commercial sexual exploitation of Korean women (Anonymous, September 9, 2011). This "push down and pop up" effect occurs when a manager or nominal owner, rather than the actual owner of a brothel or brokers supporting the network, are arrested. For instance, in 2009, Jang et al., reported that brothel owners often hire managers who act as nominal owners or managers to run their businesses to avoid law enforcement detection. According to the study, one owner ran nine brothels relying on managers. The owner only visited brothels once or twice each week to collect the proceeds. Owners also relied on different brokers for money laundering, transport or recruitment of women, and condom delivery for illegal brothel operations. The owners also hired lawyers to bail out the women after they were arrest, and bribed authorities to allow their illegal operations to continue (Jang et al., 2009, p. 86).

Another Korean prostitution case in 2006 reveals a similar structure of criminal networks. In U.S. v Merryman (2006), Diane and Jimmy Han owned two Korean brothels in South Carolina, but they resided in France. The couple hired a manager named Kang to operate their brothels in South Carolina. However, the couple only visited South Carolina "sporadically" to "collect proceeds and review activities" (U.S. v. Merryman, 2006). Kang also had a driver's license under the name of Diane Han, but with Kang's photo. (U.S. v. Merryman, 2006). This evidence suggests that commercial sexual exploitation of Korean women is not possible without perpetrators committing adjacent criminal activities supporting brothel operations (Dooley, 2012; Special Report Team, 2012; Jang et al., 2009, p. 87). Additionally, as investigations of human trafficking are often labor-intensive and time-consuming, they normally lead to misdemeanor charges with small fines. Therefore, police departments often invest resources into investigating drug trafficking or crimes with harsher penalties. While these crimes warrant serious attention and investigation, the evidence shows the importance of training law enforcement to be aware of Korean perpetrators' operational to crack down on crime efficiently.

\section{Light Penalties for Korean Traffickers}

Limited understanding of the Korean sex market among law enforcement has allowed Korean traffickers to face light penalties and small fines after committing serious crimes. For instance, in 2011, an owner and manager of a room salon were 
sentenced to 30 months and 16 months in prison, respectively, for harboring illegal aliens (Owner and Madame, 2011). However, since 2007, they profited more than four million dollars for prostituting Korean women. Most people with a basic cultural and linguistic understanding of the Korean commercial sex market know that room salons are connected to organized criminals committing federal crimes such as visa fraud and money laundering (ICE, 2013). Nonetheless, law enforcement did not prosecute the owner, the manager or their brokers for committing other crimes. Ultimately, this case reveals that law enforcement may not understand the entire scope of criminal networks supporting Korean room salons and other brothel models operating around the U.S. As a result, traffickers and their brokers are left with an incentive to profit from exploiting Korean women through commercial sex in the U.S., as they often face minimal consequences.

Massage parlors and storefront brothels are continuously considered the main business model exploiting Korean women (NHTRC, 2016; Dolinsky, 2017; Ceneviva, 2017). Although combating the exploitation in parlors is important, the evidence above shows that massage parlors are only a segment of the entire Korean commercial sex market operating in the U.S.

\section{CONCLUSION}

Commercial sexual exploitation of South Korean women has a long history in the U.S. For decades, many law enforcement agencies and NGOs have focused on combating storefront brothel models like massage parlors to fight Korean commercial sexual exploitation in the U.S. However, an analysis of legal cases and Korean American news articles shows that storefront models are a segment of entire industry currently exploiting Korean women through commercial sex. Traffickers also constantly change their tactics to avoid law enforcement detection. Therefore, today, a limited understanding of Korean commercial sex market in the U.S. makes it difficult for NGOs and law enforcement to fight commercial sexual exploitation of Korean women. It is pertinent that U.S. authorities understand the complete picture of the Korean commercial sex market in the U.S. To do this, law enforcement and NGOs must be aware of cultural and linguistic barriers that have previously allowed many parts of the Korean commercial sex market in the U.S. to remain hidden. Also, law enforcement and NGOs must be aware of trends of human trafficking that occur between South Korea and the U.S., along with information about adjacent criminal activities, victim, and perpetrator characteristics that impact how the Korean commercial sex market operates. An overall understanding of the illicit sex market exploiting Korean women provides a more comprehensive approach to combating trafficking of Korean victims in the U.S.

\section{ACKNOWLEDGMENTS}

First and foremost, I, Youngbee Dale, am grateful to Lord Jesus for His favor and grace to finish this paper. Second, I want to thank my husband and best friend, Jonathan Dale, for his unwavering support and love. Third, I want to thank Melissa Farley and Laura Lederer for encouraging me to write this paper about Korean victims of prostitution. Lastly, but not the least, I want to thank the reviewers of this paper and editor Donna Hughes for their incredible patience, support, and belief in this paper. Dignity thanks the following reviewers of this article for their time and expertise: Jody Raphael, senior research fellow, 
DePaul University College of Law, USA, and Timothy Lim, professor of political science, California State University-Los Angeles, USA.

\section{AUTHOR BIOGRAPHIES}

Youngbee Dale, M.A. (http://orcid.org/0000-0002-7824-9602) is an anti-trafficking consultant at Effective Communication Strategies, LLC., a government consulting company based in Washington D.C. area in the United States. She has a M.A. in International Politics from Regent University. Since 2005, she has served various NGOs and government entities, including, the Federal Bureau of Investigation (FBI) in Norfolk, VA, Domestic Violence Task Force, Harrisonburg, VA, Kyampisi Ministries in Uganda (2012), and Gonggam Public Law Office in South Korea. Currently, she, her husband, and two children reside in Washington D.C. area. She can be reached at ybdale@gmail.com

Amy Levesque, B.A. is a graduate student at the University of Rhode Island studying history and gender and women's studies. She has a B.A. in history, and her graduate research focuses on human trafficking in the United States and transnational trafficking in Mexico, Central America and East Asia. During the past two years, she has presented her research at regional and national conferences in Rhode Island and Nebraska and delivered a Dana Shugar Colloquium presentation at the University of Rhode Island. Currently, she resides in Johnston, Rhode Island with her husband and Labrador retriever puppy. She can be reached at amy_levesque@my.uri.edu.

\section{RECOMMENDED CITATION}

Dale, Youngbee and Levesque, Amy. (2017). Beyond massage parlors: Exposing the Korean commercial sex market in the United States. Dignity: A Journal of Sexual Exploitation and Violence. Vol. 2, Issue 4, Article 4. https://doi.org/10.23860/dignity.2017.02.04.04. Available at http://digitalcommons.uri.edu/dignity/vol2/iss4/4.

\section{REFERENCES}

3-6-9-4-6-9. (2014, January 4). Prostitution variants in Korea. In case you were curious [Blog post]. Retrieved from https://www.reddit.com/r/korea/comments/1udy8q/prostitution_variants_in korea in case you were/

33 Tex. Admin. Code §140.311- §140.360 (1977 \& Supp. 2009)

A man sold Korean women for prostitution abroad after their plastic surgery (2006, November 22), New York Korean Daily. Retrieved from http://www.koreadaily.com/news/read.asp?art id=440947

Admin. (2015, October 9). Calling all ladies in L.A. Retrieved from http://www.labamalba.com/job/1822

Admin. (2016, December 7). Plastic Surgery Club in Seoul. Retrieved from http://www.whoalba.com/gnb5/bbs/board.php?bo table=loan\&wr id=7

After 16-month investigation, N.Y. officials take down alleged prostitution operation (2012, November 20), CBS New York. Retrieved from http://newyork.cbslocal.com/2012/11/20/ny-officials-take-down-allegedprostitution-operation-after-16-month-investigation/

Anonymous, (2008, July 1). Visa Gift CARD. HeyKorea.com. Retrieved from http://mentor.heykorean.com/01 QA/View.aspx?fSeq=80992\&fCatSeq=01\&tab Index=2\&curpage $=1136 \&$ SearchType $=$ fTitle $\&$ SearchKeyword $=$ 
Anonymous, (2016, December 26). Looking for a friend to travel to the U.S. over this winter break. Crystal Café, Retrieved from http://cafe.daum.net/juuvvip

Backpage.com (2016, August 23). Real Pic Beautiful Korean Student First Day, Backpage.com Retrieved from www.backpage.com

Backpage.com. (2017, June 7). [Advertisement for Asian Massage]. Beauty sexy shower nuru three Asian beauty. Backpage.com. Retrieved from http://queens.backpage.com/WomenSeekMen/beauty-性感-섹시한-showernuru-3-asians-togetherfree-table-shower/107533143

BadAlba (n.d.). [Advertisement for Plastic Surgery Private Loan]. Ak Yeuh Al Ba homepage. BadAlba. Retrieved from http://www.badalba.com/bbs_shop/list.htm?board_code=logtest

Baer, D. (2015, September 22). Why south Korea is the plastic surgery capital of the world. Business Insider, Retrieved from http://www.businessinsider.com/southkorea-is-the-plastic-surgery-capital-of-the-world-2015-9

Bue, S. (2014, October 7). Korean norabang doumis in the U.S. disgrace the community. JTBC News. Retrieved from http://news.joins.com/article/16049399

Bue, S. (2016, February 25). Rampant Korean prostitution in Los Angeles are called fruit market. JTBC News. Retrieved from http://news.jtbc.joins.com/article/article.aspx?news id=NB11180235

Buhain, V. (2016, January 7). Sheriff: Korean women freed after bust of Seattle-area sex trafficking ring. The Seattle Globalist. Retrieved from http://www.seattleglobalist.com/2016/01/07/korean-women-freed-after-seattlesex-trafficking-bust/46181

California Massage Therapy Council: business of massage, Cal. Aseemb. B. 2194 (20152016), Chapter 411 (Cal. Stat. 2015)

California Massage Therapy, Cal. Assemb. B. 1147 (2013-2014), Chapter 406 (Cal. Stat. 2013).

Ceneviva, A. (2017, January 17). Police investigate prostitution at North Haven spa. WTNH.com. Retrieved from http://wtnh.com/2017/01/17/police-investigateprostitution-at-north-haven-spa/

Chang, J. (2015, November 20). One phone call away for women providing massage, sauna, and commercial sex. Sisa Journal. Retrieved from http://sisaus.net/전화로-부르고-마사지-하면서-사우나-하면서-성매매/

Chang, J., \& Thompson, V. (2014, June 20). South Korea's growing obsession with cosmetic surgery. ABC News. Retrieved from http://abcnews.go.com/Lifestyle/south-koreas-growing-obsession-cosmeticsurgery/story?id=24123409

Cho, J. (2016, April 14). Rapid report: we must recover our reputation from Korean prostitution cases by increasing penalties and accountability. Higoodday.com. Retrieved from http://www.higoodday.com/?mid=allNews\&act=dispOnpostContentView\&doc $\mathrm{s}$ $\underline{\mathrm{rl}=308728}$

Cho, J. \& Kim, H. (2016, January 18). Doumi prostitution websites are frowned upon. Retrieved from http://www.koreatimes.com/article/20160118/965107

Cho, S., \& Kim, Y. (2012). 3D body measurement data comparison among women in their 30 s using the $5^{\text {th }}$ and $6^{\text {th }}$ size Korea 3D measurements. Korea Design Forum, 34(20120225), 87-98. Retrieved from http://www.nl.go.kr/nl/search/bookdetail/online.jsp?contents_id=CNTS00059990329 
Choi, H. (2012, October 3). Room Salon and Karaoke business is booming during economic recession. Segye.com, Retrieved from http://m.news.naver.com/read.nhn?mode=LSD\&mid=sec\&sid1=102\&oid=022\& aid $=0002445481$

Choi, H. (2015, January 31). Reason to prostitute in the U.S. for an A-list woman: making \$200 per night in Korea while \$2000 per night in the U.S. Il Yo Si Sa. Retrieved from http://www.ilyosisa.co.kr/news/articleView.html?idxno=76951

Choi, J. (2006). South Korea: Room Salon, In A. Jones (Ed.), Man of the Global South: Reader (pp 104-109). New York, NY: University of Chicago Press.

Chong, K. (2013, February 22). A Room salon madam sentenced to two years in prison. Korea Daily.com. Retrieved from http://www.koreadaily.com/news/read.asp?art_id=1600375

Chris. (2015, July 5). Room Salons: The Real Moral Scourge on South Korean Society. Korea Expose, Retrieved from https://koreaexpose.com/room-salons-the-realmoral-scourge-on-south-korean-society/

Chung, J. (2012, October 22). Cops bust "Asian Fetish" hooker ring with four Manhattan brothels. Gothamist.com. Retrieved from http://gothamist.com/2012/10/22/cops_bust asian_fetish hooker_ring.php

Citivibe (2016, August 23). Premium Escorts. Retrieved from www.cityvibe.com

Citivue. (2017, June 4). [Advertisement for Commercial Sex]. Cityvue homepage. Cityvue. Retrieved from http://citivue.com

Crotty, J., \& Lee, K. K. (2006). The effects of neoliberal "reforms" on the postcrisis Korean economy. Review of Radical Political Economics, 38(3), 381-387. doi: $10.1177 / 0486613406290903$

Dank, M., Khan, B., Downey, P. M., Kotonias, C., Mayer, D., Owens, C., Pacifici, L., \& Yu, L. (2014). Estimating the Size and Structure of the Underground Commercial Sex Economy in Eight Major US Cities. Retrieved from Urban Institute Website: http://www.urban.org/sites/default/files/publication/22376/413047estimating-the-size-and-structure-of-the-underground-commercial-sexeconomy-in-eight-major-us-cities.pdf

Dolinsky, J. (2017, February 8). Two Korean nationals sentenced for prostitution in Larksville. Times Leader. Retrieved from http://timesleader.com/news/632985/2-korean-nationals-sentenced-forprostitution

Dooley, J. (2012, September 4). South Korean national accused of laundering money for hostess bars, massage parlors. Hawaii Reporter. Retrieved from http://www.hawaiireporter.com/south-korean-national-accused-of-launderingmoney-for-hostess-bars-massage-parlors

English language school officials and Korean publisher caught in federal immigration fraud (2013, April 11), Georgia Asia Times. Retrieved from http://gasiantimes.com/metro-asian-news/english-language-school-officialscaught-in-federal-immigration-fraud/

Eun, J. (2009, September 12). More utilize student visa to enter the U.S. for prostitution. NewsDaily.com. Retrieved from http://www.newdaily.co.kr/news/article.html?no=56244

Feather, K. (2014, November). CA governor signs massage therapy reform act. Massage Today, 14(11). Retrieved from http://www.massagetoday.com/mpacms/mt/article.php?id=14990 
Fisher, J., Cunningham, J., \& Hutchinson, B. (2012, October 22). Brooklyn man busted for running brothels in Wall Street district. New York Daily News. Retrieved from http://www.nydailynews.com/new-york/ads-offered-high-end-prostitutes260-hour-article-1.1189231

Ghosh, P. (2013, April 29). South Korea: a thriving sex industry in a powerful, wealthy super-state. International Business Times. Retrieved from http://www.ibtimes.com/south-korea-thriving-sex-industry-powerful-wealthysuper-state-1222647

Gold, L. (2014, September 2). California lawmakers pass new law regulating massage therapy. Pasadena Star-News. Retrieved from http://www.pasadenastarnews.com/government-andpolitics/20140902/california-lawmakers-pass-new-law-regulating-massagetherapy

Green, S. (2016, January 7). Large prostitution ring, Bellevue brothels shut down. Seattle Times. Retrieved from http://www.seattletimes.com/seattle-news/crime/onlinesite-where-men-rated-prostitutes-is-shut-down-charges-to-be-filed/

Han, C. (2012). Is the immigration of Korean sex workers to the United States sex trafficking or migrant smuggling? Retrieved from Brooking Institute Website: https://www.brookings.edu/wp-content/uploads/2016/06/sex-traffickinghan.pdf

Hong, K. (2005, July 4). Korean prostitution ring in California shames the Korean community. Dong A Il Bo. Retrieved from http://english.donga.com/List/3/all/26/242216/1

Huh, J. (2012, June 19). Room salons and norabang are entering in private residential areas. Korea Times.com. Retrieved from http://www.koreatimes.com/article/20120619/735547

Hwang, S. (2016, March 23). Women prostituted abroad after being trapped in private loan debt bondage. Joong Ang Ill bo. Retrieved from http://news.joins.com/article/1976712

ICE. (2013, February 22). Korean madam caught in 2012 Seattle-area prostitution bust sentenced. Immigration Customs and Enforcement. Retrieved from https://www.ice.gov/news/releases/korean-madam-caught-2012-seattle-areaprostitution-bust-sentenced

Jackman, T. (2011, June 9). Merrifield man provided karaoke companionship. Washington Post. Retrieved from https://www.washingtonpost.com/blogs/thestate-of-nova/post/merrifield-man-provided-karaokecompanionship/2011/06/09/AGBHGMNH_blog.html

Jang, J., Choo, K., \& Choi, K. (2009). Human Trafficking for Sexual Exploitation Between Korea and U.S.A. Seoul, Republic of Korea: Korea Institute of Criminology. Retrieved from https://www.dbpia.co.kr/Journal/ArticleDetail/NODE01550718

Jang, K. (2014, January 19). How far L.A. Korean commercial sex culture has gone wrong. Sunday Journal USA. Retrieved from http://sundayjournalusa.com/2014/01/19/막장까지-치달은-la-밤-문화퇴폐향락-어디까지-진화/

Kang, N. (2013, August 8). Women lured into prostitution in the U.S. with a job offered for $\$ 30,000$ a month payment. Joong Ang Ill bo. Retrieved from http://news.joins.com/article/12335413

Kelsi, D. (2014, July 25). Seven arrests made in joint prostitution sting. Fox News Carolina. Retrieved from http://www.foxcarolina.com/story/25889831/sevenarrests-made-in-prostitution-sting 
Kim, D. (2016, January 8). Police arrested 13 individuals forcing Korean women into prostitution in Seattle area. Chosun.com. Retrieved from http://news.chosun.com/site/data/html_dir/2016/01/08/2016010803120.html? Dep0=twitter\&d=2016010803120

Kim, K. (2007, May 1). The sad victims of the 180 billion won finance era. Kyung Hyang News. Retrieved from http://m.lady.khan.co.kr/view.html?med_id=lady\&artid=9673\&code=10

Kim, P. (2016, February 16). Korean women prostituted in apartment rental properties. Korea Times. Retrieved from http://www.koreatimes.com/article/20160216/970683

Kim, S. (2016, April 20). Joint bust of Korean brothels in U.S. arrests 49 people. Korea Joong Ang Daily. Retrieved from http://koreajoongangdaily.joins.com/news/article/Article.aspx?aid=3017712

Kim, Y. (2011, September 20). A wide-open door for Korean prostitution in U.S. Korea Times. Retrieved from http://ny.koreatimes.com/article/20110920/685231

Kim, Y. (2016, September 6). Police busted Korean room salons in Duluth, GA. AtlantaChosun.org. Retrieved from http://atlantachosun.org/index.php?document_srl=361642\&mid=news_online \&listStyle=viewer

Korea Daily Address book. (n.d.). Korea Daily Address book homepage. 365hananet.koreadaily.com. Retrieved from http://365hananet.koreadaily.com/yp/list.asp?mode=search\&bra code=HI\&sor $\mathrm{t}=$ A\&select=HI\&category1=L130000\&category2=L130200\&category3=H1400\&x $=9 \& \mathrm{y}=12 \& \operatorname{search}=$

Korean prostitution in L.A. exposed (2013, April 4), Korea Times. Retrieved from http://www.koreatimes.com/article/787744

Kwak, J. (2009, July 23). Korean prostituting in private residence... operating in apartments. Korea Daily. Retrieved from http://www.koreadaily.com/news/read.asp?art id=881859

L.A. Bamalba. (2017, June 4). [Advertisement for Doumi]. LA Bamalba homepage. L.A.BamAlba. Retrieved from http://www.labamalba.com/job/a1822

L.A. Bamsarang (n.d.). [Advertisement for Room Salon] L.A.BamSarang. L.A. BamSarang. Retrieved from http://www.labamsarang.com

Lee, D. (2015, October 2). Asian prostitutes including Korean women raped at hotels in New York.... Manhattan police raise awareness in Korean language. Chosun.com. Retrieved from http://news.chosun.com/site/data/html_dir/2015/10/02/2015100201532.html? Dep0=twitter\&d=2015100201532

Lee, D. (2016, March 4). Celebrity prostitution in Los Angeles. Sisa Journal US. Retrieved from http://sisaus.net/la 에서-터진-원정-연예인-성매매-현장/;

Lee, J. (2011, March 23). Bang suck jip secretly operate in residential areas in Annandale, VA. Korea Times. Retrieved from http://dc.koreatimes.com/article/645846

Lee, J. (2014, February 1). New York Korean Prostitution network bring disgrace to the Korean community. HeyKorean.com. Retrieved from http://www.heykorean.com/HK News/view.asp?aid=99667

Lee, J. (2014, July 16). Four Korean women received prison sentence for running a brothel and laundering money. Korea Daily. Retrieved from http://www.koreadaily.com/news/read.asp?art_id=2680421 
Lee, J. (2016, May 11). U.S.-Korean celebrity sex trafficking case behind the story. Chicago Korea Daily. Retrieved from

http://m.koreadaily.com/read.asp?art_id $=4257274$

Lee, J. (2016). Field Study: obstacles of women's escape from prostitution- effects of drug, alcohol, diet, and forced plastic surgery of women in prostitution. Women's Human Rights, 15, 64-74. Retrieved from http://www.stop.or.kr/?act=\&mid=news_resource_research\&vid=\&ruleset=sear chBeluxe\&category_srl=\&search_target=title\&search_keyword=여성 과+인 권

Lee, J., \& Kim, H. (2006)._Survey analysis of prostitution after the enactment of the 2004 Act on the Punishment of Intermediating in the Sex Trade and Associated Acts. Namseoul University. Retrieved from National Assembly Library of Korea Website: http://www.nanet.go.kr/

Lee, T. (2015, May 5). Police shut down Korean American norabangs. Cho Sun.com. Retrieved from http://news.chosun.com/site/data/html_dir/2015/05/06/2015050604223.html

Lee, W. (2014, July 17). Some engage in prostitution and abuses drug. Korea Times. Retrieved from http://www.koreatimes.com/article/865187

Lim, T. C., \& Yoo, K. (2008). Final report: the dynamics of trafficking, smuggling and prostitution: an analysis of Korean women in the U.S. commercial sex industry. Retrieved from

https://www.academia.edu/3605690/The_Dynamics_of_Trafficking_Smugglin $\mathrm{g}$ and Prostitution An Analysis of Korean Women in the U.S. Commerci al Sex Industry

Makeup grows in popularity among men in South Korea (2012, September 17). CBS News, Retrieved from http://www.cbsnews.com/news/makeup-grows-in-popularity-among-menin-south-korea/

Massage Therapist; conviction for sexual offense; license suspended for certain time periods; penalties, Ga. Sen. B. 364 (2009-2010), Chapter 24A (Ga. Sen. 2009).

May, M., \& Fitzmaurice, D. (2006, October 8). A youthful mistake/You Mi was a typical college student, until her first credit card got her into trouble. San Francisco Gate. Retrieved from http://www.sfgate.com/news/article/A-YOUTHFULMISTAKE-You-Mi-was-a-typical-college-2487822.php\#photo-2647748

McMar, L. (2015, September 15). South Korea's cosmetic surgery craze is still booming, News.com.au., Retrieved from http://www.news.com.au/lifestyle/beauty/cosmetic-surgery/south-koreascosmetic-surgery-craze-is-still-booming/newsstory/2183fc1b0c4a90193104ea9031e36fle

Moon, D. (2014, February 5). Prosecutor arrested a woman in her 40s for brokering prostitution of women between U.S. and Korea. Kukinews.com. Retrieved from http://www.kukinews.com/news/article.html?no=182724

Moon, S. (2015, September 2). Story of women in prostitution abroad. Illyosisa.com. Retrieved from ilyo.co.kr/?ac=article view\&entry id=140249

N.Y. BamAlba (n.d.). [Advertisement for Room Salon]. N.Y. BamAlba homepage. N.Y. BamAlba. Retrieved from http://www.bamalbaworld.com

Noh, S. (2016, December 15). Foreign language course abroad and internship are "a must" to obtain job opportunity. News One. Retrieved from http://news1.kr/articles/?2858611

Norabang doumi lured with high paying job offer (2014, May 11), Sunday Journal USA. Retrieved from http://sundayjournalusa.com/2014/05/11/노래방-도우미의애환-돈-많이-벌수-있다는-유혹에/ 
Ofek, E., Kim, S., \& Norris, M., (2015). CJ E\&M: Creating a K-Culture in the U.S [Teaching notes]. Retrieved from http://www.hbs.edu/faculty/Pages/item.aspx?num=48426

Oh S. (2014, August 23)._Korean prostitution network caught...running residential brothels through internet and social media advertisement in an apartment rental property. L.A. Korea Daily. Retrieved from http://www.koreadaily.com/news/read.asp?art_id=2762726

Oh, S. (2013, November 27). Online Prostitution is flourishing through websites, smartphone, and social media. Korea Daily. Retrieved from http://www.koreadaily.com/news/read.asp?art id=2152704

Oh, S. (2015, February 17). Women lured with Hollywood entertainment industry job offer, KoreaDaily.com, Retrieved from http://www.koreadaily.com/news/read.asp?art id=3199766

Owner and Madame of Korean room salon in Virginia sentenced (2011, April 15), Immigration and Customs Enforcement. Retrieved from https://www.ice.gov/news/releases/owner-and-madame-korean-room-salonvirginia-sentenced

Park, J. (2016, September 8). FBI shut down two Korean room salons in Duluth, Georgia. Korea Times Alabama. Retrieved from http://koreatimesalabama.com/news/28871

Park, S. (2013, August 13). Brokers arrested for luring young women into U.S. prostitution with $\$ 35000$ monthly income. Kyung Hyang Shinmoon. Retrieved from

http://news.khan.co.kr/kh news/khan art view.html?artid=201308131551171\& code $=940202$

Park, S. (2013, May 30). Korean Town prostitution advertised through Kakao Talk. Korea Daily. Retrieved from http://news.joins.com/article/11662913

Philips, S. (2015, November 23). Defendant in prostitution case appears in federal court. WDAM.com. Retrieved from http://www.wdam.com/story/30589652/defendant-in-prostitution-caseappears-in-federal-court

Polaris Project (n.d.). Fake Massage Businesses. Retrieved from https://humantraffickinghotline.org/sex-trafficking-venuesindustries/fakemassage-businesses

Polaris Project. (2014). 2014 State Ratings on Human Trafficking Laws. Retrieved from https://polarisproject.org/sites/default/files/2014-State-Ratings.pdf.

Proffitt, C. (2007, January 23). Carmel ordinance gets tough on massage parlors. WTHR.com. Retrieved from http://www.wthr.com/article/carmel-ordinancegets-tough-on-massage-parlors

Prostitution penetrates Korean Town (2016, June, 10), L.A. Korea Daily. Retrieved from http://m.ny.koreadaily.com/news/read.asp?art id=4344377

Prostitution widespread among Norabang doumis (2009, March 8). Sunday Sisa USA.com, Retrieved from http://sundayjournalusa.com/2009/03/08/실 태추적la 한인타운-노래방-불법퇴폐영업-온상/

Ramirez, E. (2017, March 27). The Escort bars that Uber execs reportedly visited are a regular affair in South Korea. Forbes.com, Retrieved from https://www.forbes.com/sites/elaineramirez/2017/03/27/the-escort-bars-thatuber-execs- reportedly-visited-are-a-regular-affair-in-southkorea/\#687854bb2f17 
Report on Korean prostitution in California (2012, November 12), Ill Gan Best. Retrieved from http://www.ilbe.com/354799442

Shin, P. (2016, September 28). South Korea is room salon republic: 13000 entities... 4 out of 10 offer prostitution. Retrieved from http://www.womennews.co.kr/news/98135

Special Report Team. (2012, January 12). L.A. Room Salons crackdown after Seattle arrest. Sunday Journal USA. Retrieved from

http://sundayjournalusa.com/2012/01/19/추적취재-시애틀-이어-la 지역-가디나한인-룸살롱-급습/

The reality of Korean prostitution in L.A. (2004, October 22). Sunday Sisa USA.com, Retrieved from http://sundayjournalusa.com/2004/10/22/la-요지경-「밤업소」 -진풍경-실태취재-1 탄/

United States v. Merryman, 4:06-cr-00480-JFA (S. D. of S. C., 2006). Retrieved from https://www.gpo.gov/fdsys/pkg/USCOURTS-tned-3_97-cv00080/pdf/USCOURTS-tned-3_97-cv-00080-1.pdf

United States v. Ryan Kim et al., 16 Mag 2398, Complaint. (S.D.N.Y. April 13, 2016), https://www.justice.gov/usao-sdny/file/840766/download

United States v. Won, No. 1:1 l-MJ-340 Aff. (U.S., April 29, 2011).

Womak, A. (2014, July 15). Four sentenced in federal Macon massage parlor case. Macon.com. Retrieved from http://www.macon.com/news/local/crime/article30134475.html

Women prostituted abroad after being trapped in private loan debt-bondage (2016, March 22), Korea Daily. Retrieved from http://www.koreadaily.com/news/read.asp?art id=4111232

Wright, T. (2015, June 2). Monterey imposing stricter rules on massage parlors. Monterey County Herald. Retrieved from http://www.montereyherald.com/article/NF/20150602/NEWS/150609937

Yoo, N., Chong, S. A., Won, M. K., \& Kim, J. H. (2016). 2016 Special Forum- Conspiracy among Commercial Sex Business, Private Loan Sharks, and Plastic Surgeons: who is the perpetrator? Retrieved from E Loom Website: http://www.eloom.org/fileboard/39

Yoon, P. (2010, November 29). Over 1000 Korean female students prostituted in Australia. Donga Weekly. Retrieved from http://weekly.donga.com/List/3/all/11/91113/1

Yu, R. (2008, November 17). U.S. adds 7 countries to visa waiver program. USA Today. Retrieved from http://usatoday30.usatoday.com/travel/news/2008-11-16-visawaiver-program-expands N.htm

Yushuvayev v. United States, No. 07-CV-1338 (E.D.N.Y. Jan. 18, 2008), 532 F. Supp. 2d 455. 